\title{
Parametric Evaluation of Bio-Digestion Process-A Review
}

\author{
Manish Baweja ${ }^{1}$, Prashant Baredar ${ }^{2}$, R. R. Lal ${ }^{1}$ \\ ${ }^{1}$ Department of Mechanical Engineering, AISECT University, Bhopal, India \\ ${ }^{2}$ Department of Energy, Maulana Azad National Institute of Technology, Bhopal, India
}

Email address:

Manishbaweja2001@rediffmail.com (M. Baweja)

\section{To cite this article:}

Manish Baweja, Prashant Baredar, R. R. Lal. Parametric Evaluation of Bio-Digestion Process-A Review. American Journal of Energy Engineering. Vol. 6, No. 1, 2018, pp. 6-9. doi: 10.11648/j.ajee.20180601.12

Received: March 14, 2018; Accepted: April 18, 2018; Published: May 18, 2018

\begin{abstract}
Anaerobic digestion is the biodegradation of the organic waste with the aid of bacteria which performs it work in the absence of oxygen. The main objective of anaerobic digestion is the degradation and destruction of organic substances, with consequent reduction of the pathogens. \& odorous emissions. Anaerobic digestion process consists of four major steps: hydrolysis, acidogenesis, acetogenesis an methanogenesis vegetable wastes are a fine substrate with possibility to produce methane and are available. In abundance This work reviews the various parameters affecting the biodigestion process. A careful consideration when selecting the working method parameter such, organic loading rate (OLR), C/N ratio, Gas production rate inoculums to substrate ration (ISR) temperature \& pressure hydraulic retention time, Electricity generation calculations are given. Improvement in $\mathrm{C} / \mathrm{N}$ ratio, higher bio-degradability, effective volatile solids (VS) elimination, ecofriendly sludge production has been regarded as advantage of co-digestion process.
\end{abstract}

Keywords: Parametric Evaluation, Energy Recovery, Renewable Sources, C/N Ratio, Organic Loading Rate, Biogas, Methane, $\mathrm{pH}$

\section{Introduction}

IBiodigestion or anaerobic digestion $(\mathrm{AD})$ is a organic process that occur as organic material is decomposed by bacteria in the absence of oxygen. As the bacteria decompose the organic matter, biogas is formed and captured. Biogas mainly consists of about $60 \%$ methane and $40 \%$ carbon dioxide. The remaining byproduct is called Digestate.

Biogas can be combusted to give heat $\&$, electricity. while the biogas can be upgrade to natural methane, called biomethane, by removing other gases. This pure flow of biomethane can be used as a alternate for natural gas. Digestate which is the extra material in the $\mathrm{AD}$ process. contain precious plant nutrients like nitrogen and potassium. $\&$ can be used as a soil conditioner \& fertilizer

Anaerobic digestion is a activity in which organic material is broken down by bacteria \& microorganisms in the absence of oxygen. The process is used for domestic or industrial purposes to produce fuels or to manage waste. It is a source of methane and occurs naturally in soils and in lake and ocean basin sediments.

The digestion process starts with hydrolysis of the feedstock. Insoluble organic polymers like carbohydrates, are broken down to soluble derivatives that become available for other bacteria. Acidogenic bacteria then converts the sugars and amino acids into carbon dioxide, hydrogen, ammonia, and organic acids and resulting organic acids into acetic acid. Finally Methanogens convert these products to methane \& carbondioxide

Anaerobic digestion is extensively used as renewable energy source. The process produces a biogas, consisting of methane \& carbon dioxide and some amount of other 'contaminant' gases. This biogas can be used directly as fuel, in combined dual fuel or gas engines or upgraded to natural gas-quality bio-methane. The nutrient-rich digestate left as bye product can be used as fertilizer.

\section{The Biogas Production Process}

Process stage

The anaerobic digestion activity consists of four steps s i.e hydrolysis, acidogenesis, acetogenesis and methanogenesis. 
respectively The complete process can be denoted by the chemical reaction, in which organic material such as glucose is converted into carbon dioxide $\left(\mathrm{CO}_{2}\right)$ and methane $\left(\mathrm{CH}_{4}\right)$ by the anaerobic bacteria

$$
\mathrm{CH}_{12} \mathrm{O}_{6} \rightarrow 3 \mathrm{CO}_{2}+3 \mathrm{CH}_{4}
$$

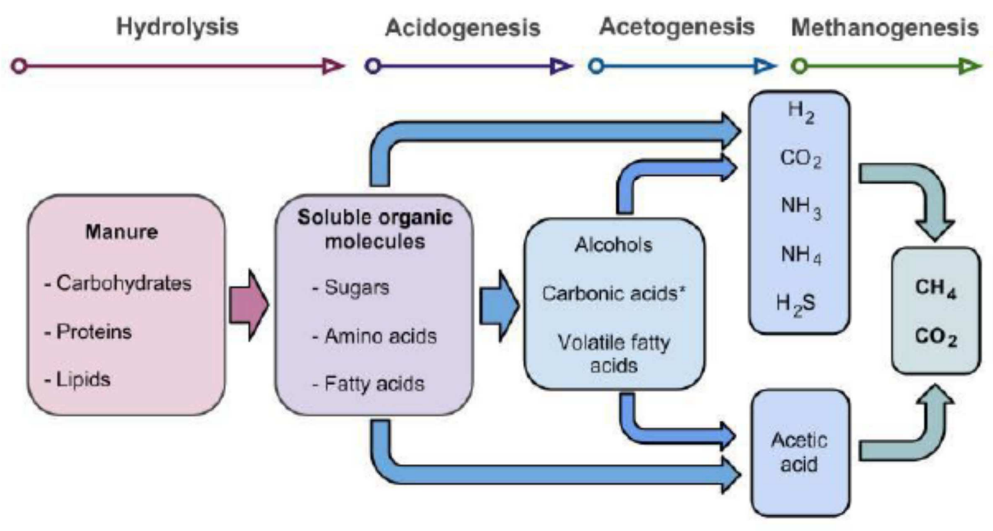

Figure 1. The Main Stages in Biogas Production.

\subsection{Hydrolysis}

Generally, biomass consists of large organic polymers., these chains must first be broken down into their smaller constituent parts so that bacteria in anaerobic digesters starts working on them. These constituent parts, or monomers, such as sugars, are readily available to other bacteria. Hydrolysis involves the process of breaking these chains and dissolving the smaller molecules into solution

\subsection{Acidogenesis}

It is the further breakdown of smaller molecules obtained as a result of hydrolysis by acidogenic bacteria. It results in formation of volatile fatty acids along with ammonia, carbon dioxide, and hydrogen sulfide. The process of acidogenesis is similar to the way milk sours

\subsection{Acetogenesis}

The third step in anaerobic digestion is acetogenesis. In this stage vfa obtained during the acidogenesis phase are reacted by acetogens to produce acetic acid, along with hydrogen and carbon diox

\subsection{Methanogenesis}

The final step of anaerobic digestion is methanogenesis. Here, methanogens convert acetic acid into into methane, carbon dioxide, and water. These components make up the majority of the biogas emitted from the system. Methanogenesis occurs between $\mathrm{pH} 6$ and $\mathrm{pH}$ 8.5. The remaining, indigestible material the bacteria cannot use is known as digestate..

\section{Factors Affecting the Anaerobic Digestion Process}

\subsection{Organic Loading Rate}

The organic loading rate is important for efficient breakdown of materials it is the amount of solids added into the digester per unit volume per day and is generally denoted as OLR $\mathrm{kg} \mathrm{VS} / \mathrm{L} . \mathrm{d}$. the loading rate helps in determining the amount (mass) of feed stockto be added in a digester per day depending on the volume or size of digester to yield maximum biogas. The knowledge of the OLR for a particular plant helps since feeding over the OLR doesn't necessarily result inan increase in the gas produced. In a study to improve the biogas production for, the OLR was reported to be 2.4-2.51 g/L. $\mathrm{d}$ for different digesters.

\section{2. $C: N$ Ratio}

The relationship between the amount of carbon and nitrogen present in feedstock is represented by the $\mathrm{C} / \mathrm{N}$ ratio. It is a very important process parameter of the process as a low ratio can cause ammonia inhibition whereas a high ratio will lead deficiency (The adjustment of the ratio to be within the optimum range (25-30) can be achieved through the codigestion of different waste streams Optimum $\mathrm{C} / \mathrm{N}$ ratios in anaerobic digesters are between $20 \& 30$. A high $\mathrm{C} / \mathrm{N}$ ratio results in lower gas production because of rapid consumption of nitrogen by methanogens and results in lower gas production. On the other hand, a lower $\mathrm{C} / \mathrm{N}$ ratio causes $\mathrm{pH}$ values exceeding 8 , and ammonia accumulation which is toxic to methanogenic bacteria. Optimum $\mathrm{C} / \mathrm{N}$ ratios of the digeste rmaterials can be achieved by mixing materials of high and low $\mathrm{C} / \mathrm{N}$ ratios, such as organic solid was temixed with animal manure or sewage.

\subsection{Gas Production Rate}

\subsubsection{Effect of pH Alteration in Biogas}

The $\mathrm{pH}$ value is represented as the logarithm of the reciprocal of the hydrogen ion concentration in $\mathrm{gm}$ equivalent per litre of solution. $\mathrm{pH}$ value in the range $0-7$ represents acidic solution and in the range 7-14 indicates the alkaline solution. The bacteria present during biodigestion require a neutral or mildly alkaline environment - a too acidic or too alkaline environment damages the bacteria. 
Ideal $\mathrm{pH}$ value is between 7.0-8.0 but can go up or down by a further 0.5 . In the initial stages of of digestion, the $\mathrm{pH}$ value may be around 6.0 or less, however during final stage when the $\mathrm{pH}$ value higher than 7.0 is maintained since methane formers are sensitive to acidity. The $\mathrm{pH}$ value depends on the ratio of acidity and alkalinity and the carbon dioxide content in the digester, the determining factor being the density of the acids. Under normal process of digestion, the concentration of acetic acid should be below 1800 parts per million too high a concentration will greatly slows down the action of the methanogenic microorganisms. The survival of methanogenic bacteria also depends on the acidity of the environment that they are in: methanogenesis requires a nearneutral $\mathrm{pH}$ (between 6.5 and 7.5). With a decrease in $\mathrm{pH}$ gas production slows down and can lead to accumulation of acids.

\subsubsection{Temperature \& Pressure}

The temperature in anaerobic digestion greatly affects the biogas production. The methane forming bacteria works best in the temperature between $30^{\circ} \mathrm{C}$ to $40^{\circ} \mathrm{C}$ or between $48^{\circ} \mathrm{C}$ to $60^{\circ} \mathrm{C}$ and pressure of about 1.2 to 1.4 bars absolute. This is due to fact that two different types of bacteria expands best in these two different ranges, but the high temperature bacteria are much more sensitive to ambient influences. The rate of gas production increases with the increase in temperature but the percentage of methane reduces. It is found that temperature between $30^{\circ} \mathrm{C}-35^{\circ} \mathrm{C}$ are most efficient for stable and continuous production of methane. If this range is not maintained, Biogas produced will have a higher percentage of carbon dioxide and other gases than within this range. The biogas production is fastest during summer and it decreases during winter due to lower temperature. Below $20^{\circ} \mathrm{C}$ temperature the rate of gas production falls sharply and it almost stops at about $10^{\circ} \mathrm{C}$. Also methanogemic bacteria are sensitive to changes in temperature, a sudden change exceeding $30^{\circ} \mathrm{C}$ will affect production, and therefore one must ensure relative stability of temperature. Thus, in cold climates, it digester is heated to about $35^{\circ} \mathrm{C}$. There are three digestion operational temperature ranges. Thermophilic digestion occurs above $45^{\circ} \mathrm{C}$. Between $25^{\circ} \mathrm{C}$ and $45^{\circ} \mathrm{C}$ it is mesophilic digestion and Psychrophilic digestion occurs at below $25^{\circ} \mathrm{C}$, or below room temp

\subsubsection{Inoculum (ISR)}

Inoculum which is also called seeding is adding a substance into a digester for assisting the anaerobic digestion process by providing the necessary bacteria for the biodegradation. Slurry from previous digestion can be used, cattle, chicken, pig manure, and slurry from waste water treatment plants can be used. The ratio at which it is added in respect to the substrate is called inoculum substrate ratio (ISR). This ratio is very important as it can either hinder or enhance $r$ the complete digestion of the substrate and thus resulting in low and high biogas and methane yields respectively.

\subsubsection{Hydraulic Retention Time}

Hydraulic retention time is the time the solids or slurry remains inside the digestorr during the anaerobic climate digestion process. HRT differs depending on type climates HRT can go as high as 100 days. The longer retention period needs large of substrate and condition with which the anaerobic digestion is performed. For example in tropical climate countries have shorter HRT between 30-50 days, whereas in colder size digestor and it allows more digestion of feedstock. for a single-stage thermophilic digestion, retention times is normally takes around 15 days. While in a two-stage mesophilic digestion, retention time iaries between 15 and 40 days.

\subsubsection{Nutrients}

The microorganisms require

Micronutrients for their growth and stability. Some of the nutrients are readily available in most of the substrates, but an addition may be needed when necessary. Nitrogen phosphorus and trace elements such as calcium, sulphur, magnesium, potassium, nickel, iron, zinc, cobalt, copper and manganese are good source of nutrients Addition of these nutrients will lead to improved digester performance and result in improved methane production.

\subsection{Electricity Generation Calculation}

$1 \mathrm{~kg}$ waste yields $0.35 \mathrm{~cm}^{3}$ of Bio-gas

$1 \mathrm{~m}^{3}$ of Biogas yields $23 \mathrm{M}$ joule of electricity

Various methods are available. To generate electricity from bio gas In principle, the chemical energy of the combustible gases is converted to mechanical energy in a dual fuel engine. This mechanical energy then activates a generator to produce electrical power.

The efficiency of engine is 25 percent and efficiency of generator is 80 percent

Thus in order to produce Electricity for $100 \mathrm{~m} 3$ of biogas the amount of Biogas practically required is $100 / 0.25 * 0.8=500 \mathrm{~m}^{3}$

\section{Conclusion}

This review shows the various parameters that affect a Bio digestion Process. Organic loading rate which is amount (mass) of feed stock to be added in a digester per day depending on the volume or size of digester to yield maximum biogas after this. Optimum $\mathrm{C} / \mathrm{N}$ ratios is required for maximum yield of Biogas $\&$ is obtained by mixing materials of high and low $\mathrm{C} / \mathrm{N}$ ratios, such as organic solid waste mixed with animal manure...Optimum level of temperature and pressure is also required for high production rate of gas besides this $\mathrm{pH}$ level also plays a important role in Bio-digestion Process. Other factors like Inoculum \& hydraulic retention time also affect the Bio-digestion process.

\section{References}

[1] Remade Scotland. Overview of research achievements and perspectives. Bioresource technology, 74:3-16. 
[2] W. Yuanyuan, Z. Yanlin, W. Jianbo, and M. Liang, "Effects of volatile fatty acid concentrations on methane yield and methanogenic bacteria," Biomass and bioenergy, vol. 33, pp. 848-853, 2009.

[3] Monnet, F. (2003): An Introduction to anaerobic digestion of organic wastes.

[4] K. C. Surendra, D. Takara, A. G. Hashimoto, and S. K. Khanal, "Biogas as a sustainable energy source for developing countries: Opportunities and challenges," Renewable and Sustainable Energy Reviews, vol. 31, PP846-859, 3// 2014.

[5] V. S. Patil and H. V. Deshmukh, "A review on optimization of parameters for vegetable waste biomethanation," Int. J. Curr. Microbiol. App. Sci, vol. 4, pp. 488- 493, 2015.

[6] Ireen Maile +, Edison Muzenda and Charles Mbohwa "Optimization of Biogas Production through Anaerobic Digestion of Fruit and Vegetable Waste: A Review"2016 7th International Conference on Biology, Environment and Chemistry Volume 98 of IPCBEE (2016) PP1-9.

[7] Robert M. W. Ferguson 1, Fr_ed_eric Coulon, Raffaella Villa Organic loading rate: A promising microbial management tool in anaerobic digestion. 2016 PP348-356.

[8] S. Sathish, S. Vivekanandan Parametric optimization for floating drum anaerobic bio-digester using Response Surface Methodology and Artificial Neural Network 2016 PP32973307.
[9] Rishi Pareek and Hemant J. Nagarsheth Preparation Parametric Comparison and PerformanceEvaluation of FRP and HDPE Type Biogas Digesters Journal of Clean Energy Technologies, Vol. 4, No. 5, September 2016PP357-361.

[10] Das A. and Mondal C. Biogas Production from Co-digestion of Substrates: A Review International Research Journal of Environment Sciences ISSN 2319-1414 Vol. 5(1), 49-57, January (2016).

[11] Antony. P. Pallan, Dr. S. Antony Raja, Dr. C. G. Varma: Operational Conditions of Anaerobic Digestion and their optimization for enhanced gas Production A Review International Journal of Scientific and Research Publications, Volume 7, Issue 7, July 201749 ISSN 2250-3153PP49-55.

[12] Gurinderpal Singh, V. K. Jain and Amanpreet Singh Effect of Temperature and other factors on Anaerobic Digestion Process, responsible for Bio Gas Production International Journal of Theoretical and Applied Mechanics. ISSN 09736085 Volume 12, Number 3 (2017) pp. 637-657.

[13] Azadeh Babaee, Jalal Shayegan Effect of organic loading rates (OLR) on production of methane from anaerobic digestion of vegetables waste PP411-417.

[14] Hiya Dhar Pradeep Kumar Sunil Kumar Somnath Mukherjee, Atul N. Vaidya Effect of organic loading rate during anaerobic digestion of municipal solid waste PP-56-61. 